\title{
Batagur baska (Gray 1830) - Northern River Terrapin
}

\author{
Edward O. Moll ${ }^{1}$, Kalyar Platt ${ }^{2}$, Steven G. Platt ${ }^{3}$, \\ Peter Praschag ${ }^{4}$, and Peter Paul van Dijk ${ }^{5}$ \\ 1941 West Sunset Knoll Lane, Tucson, Arizona 85704 USA [e.o.moll@att.net]; \\ ${ }^{2}$ Biological Sciences Program, Faculty of Science, \\ Chulalongkorn University, Bangkok, 10330 Thailand [kalyarplatt@gmail.com]; \\ ${ }^{3}$ Department of Biology, P.O. Box C-64, Sul Ross State University, Alpine, Texas 79832 USA [splatt@sulross.edu]; \\ ${ }^{4}$ Turtle Conservancy, Behler Chelonian Center, P.O. Box 1289, Ojai, California 93024 USA [peter@praschag.at]; \\ ${ }^{5}$ Conservation International, 2011 Crystal Drive, Suite 500, \\ Arlington, Virginia 22202 USA [p.vandijk@conservation.org]
}

SumMary.-The northern river terrapin,Batagurbaska (Family Geoemydidae), is a large (carapace length to $59 \mathrm{~cm}$ ) critically endangered river turtle that previously occupied most rivers and estuaries of South Asia (India, Bangladesh, and Myanmar). Populations of river terrapins occurring in Southeast Asia (Thailand, Cambodia, Malaysia, and Indonesia) previously referred to this species are now considered a separate closely-related species, the southern river terrapin, Batagur affinis. Exceptionally large concentrations of this species that resided in the Hugli River of West Bengal in India and the Ayeryawady Delta in Myanmar during the 19th and early 20th centuries are now extirpated. Nesting throughout the northern river terrapin's former range is now extremely rare and the product of only a few scattered survivors. The terrapin's demise has resulted from extensive exploitation of its flesh and eggs, exacerbated by indirect factors, including habitat alteration and destruction (e.g., sand-mining, dam building, water projects, and pollution) that have degraded the turtle's nesting areas and feeding habitat. Recently, remnant populations have also suffered from the introduction of efficient mechanized fishing craft with lethal wide-area nets throughout much of the remaining habitat. Conservation action for the terrapin has been woefully inadequate. Ideally, the species and its eggs require complete protection throughout its range. In India and Bangladesh, extant terrapins now appear to be so few that unless some previously unknown viable population is discovered, the only recourse may be to capture as many of the remaining wild individuals as possible to keep in captive breeding facilities until such time as it is feasible to re-establish a wild population in one or more sanctuaries. Less is known about the species' status in Myanmar. Additional surveys are needed for estuarine habitats in the poorly-known eastern and southeastern river systems in Myanmar to determine if viable populations survive, and if so, to identify nesting sites and critical feeding areas.

Distribution. - Bangladesh, India, Myanmar. The northern river terrapin historically inhabited estuarine habitats from Orissa and West Bengal in India, eastward through Bangladesh to at least the Ayeyarwady, Bago, and possibly the Thanlwin (Salween) and Sittaung rivers in Myanmar. Reports of river terrapin in the Indus and Mahanadi rivers require verification. It is presently unknown if terrapin sightings in southernmost Myanmar represent the northern or southern river terrapin (B. affinis).

Synonymy. - Emys baska Gray 1830a, Testudo baska, Batagur (Batagur) baska, Tetraonyx baska, Tetronyx baska, Batagur baska, Batagur baska baska, Emys batagur Gray 1830b, Clemmys (Clemmys) batagur, Tetraonyx batagur, Batagur batagur, Batagur batagur batagur, Trionyx (Tetraonyx) cuvieri Gray 1830b, Tetraonyx longicollis Lesson 1831, Tetronyx longicollis, Clemmys longicollis, Tetraonyx lessonii Duméril and Bibron 1835, Hydraspis (Tetronyx) lessonii, Emys tetraonyx Temminck and Schlegel 1835.

SuBSPECIES. - None currently recognized.

STATUS. - IUCN 2009 Red List: Critically Endangered A1cd (assessed 2000); CITES: Appendix I; US ESA: Endangered; Indian Wildlife (Protection) Act: Schedule I; Myanmar: Protection of Wildlife, Wild Plants and Conservation of Natural Areas Law: Protected.

Taxonomy. - The northern river terrapin was introduced to science as one of several tropical Asian turtles in the sketches of Buchanan Hamilton that were published by John E. Gray, longtime Keeper of Zoological Collections at the British Museum, in his Illustrations of Indian Zoology from 1830 to 1835 . Plate 75 in Volume 1 of this work (1830a) depicted what appears to be a juvenile northern river terrapin with the label of "baska terrapin, Emys baska."

Gray, at times, was guilty of describing the same species under more than one name; the river terrapin is an example. In the same year, he published two other names for the terrapin,Trionyx (Tetraonyx) cuvieri and Emys batagur (1830b). 


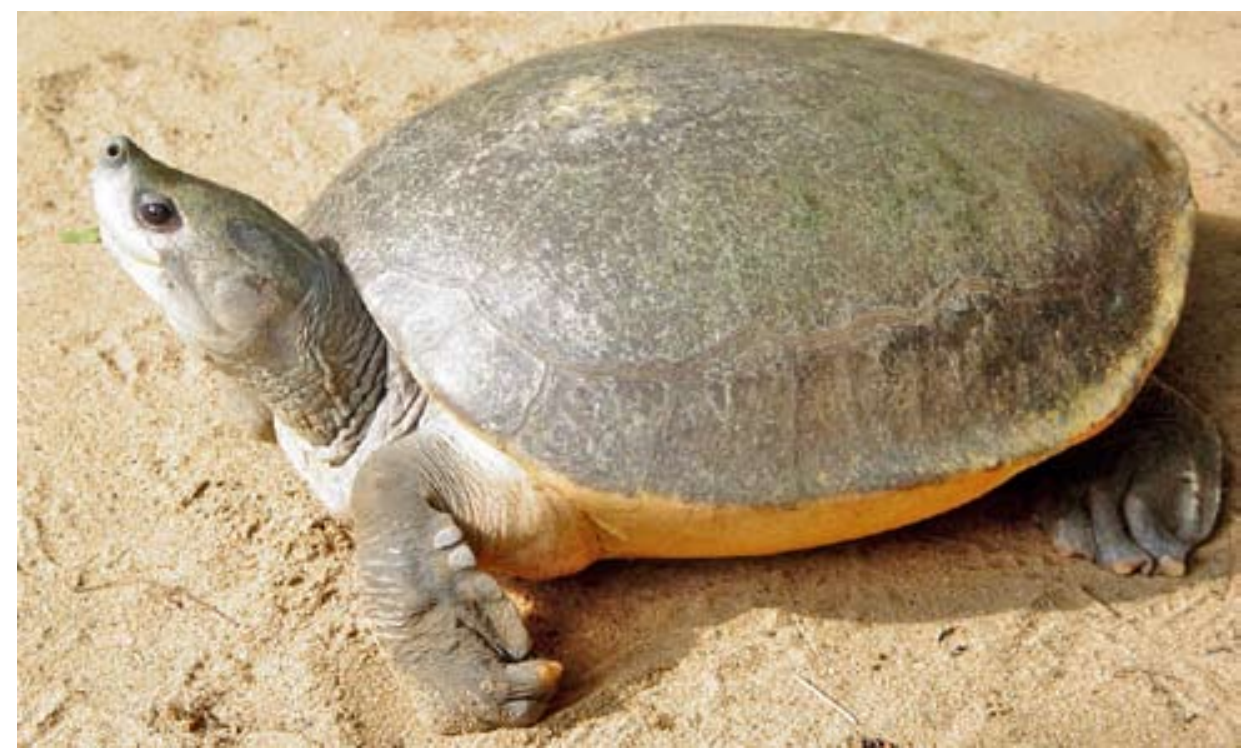

Figure 1. Captive female Batagur baska from the Madras Crocodile Bank believed to be from the Indian Sundarbans. Photo by Rick Hudson.

The genus name Tetraonyx ("four claws" in contrast with the trionychids or "three claws") subsequently gained wide acceptance as the genus. Combinations using that genus included T. longicollis Lesson (1831), T. lessonii Duméril and Bibron (1835), and T. affinis Cantor (1847), the latter now considered a separate species. Tetraonyx proved to be a junior homonym of a coleopteran and had to be replaced. The spelling variant Tetronyx Lesson 1832, is considered a nomen novum (a replacement name) (Bour 2009), but has rarely been used, and is now a nomen oblitum. Temminck and Schlegel (1835) used the epithet tetraonyx as a replacement species name for Tetronyx longicollis Lesson, and placed it in Emys. The combination Batagur baska was first used by Gray (1856). The convoluted history of names used for Batagur baska was reviewed by Bour (2009), who included illustrations of the types of Tetraonyx longicollis Lesson 1831 and Tetraonyx lessonii Duméril and Bibron 1835.

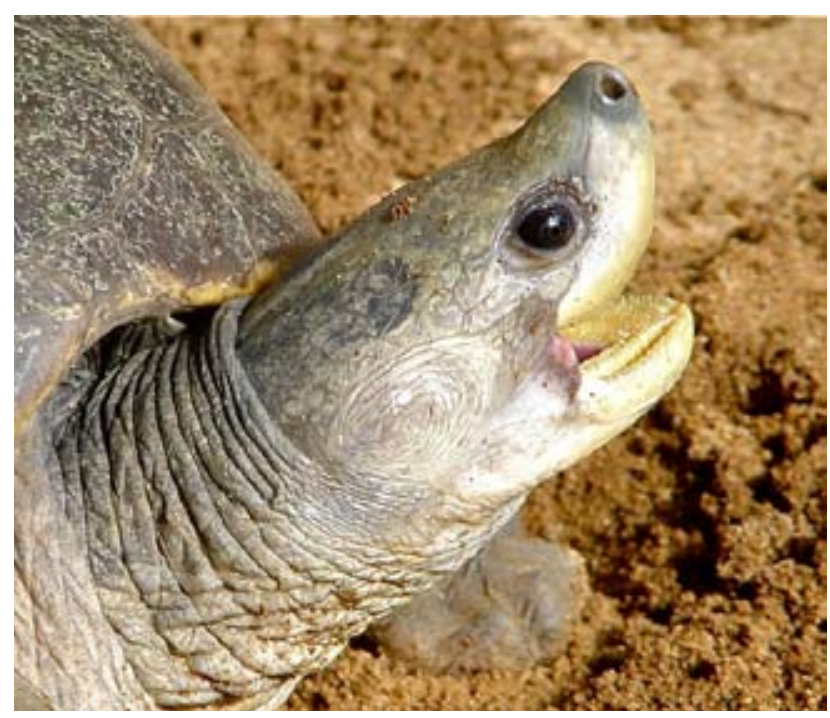

Figure 2. Close up of the above female Batagur baska, showing denticulate jaw and ridges. Photo by Rick Hudson.
The river terrapins' closest relatives appear to be herbivorous, highly aquatic species presently in the genera Batagur, Hardella, Morenia, and Pangshura. Morphological characters shared by this group include a large foramen orbito-nasale, a broad secondary palate, serrate tomia, strong plastral buttresses, an entoplastron lying anterior to the humero-pectoral sulcus, and fourth marginal scutes contacting the second pleural scutes. In males, the costoperipheral foramina persist throughout life. Various authors have debated the relationships among these genera (e.g., Loveridge and Williams 1957; McDowell 1964; Hirayama 1984; Gaffney and Meylan 1988; Capler and Moll 1990; Spinks et al. 2004).

Praschag et al. (2007), using DNA sequences of the mitochondrial cytochrome $\mathrm{b}$ gene, examined the relationships of species then constituting the genera Batagur, Callagur, Kachuga, Pangshura, and Hardella. A key finding was that

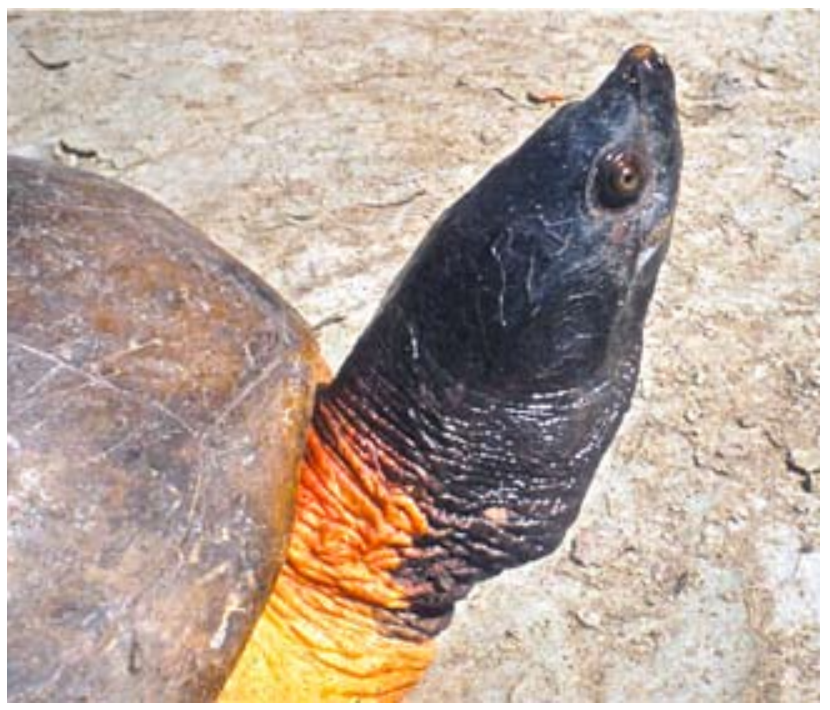

Figure 3. Male Batagur baska in breeding coloration from the Bangladesh Sundarbans. Photo by S.M.A. Rashid. 


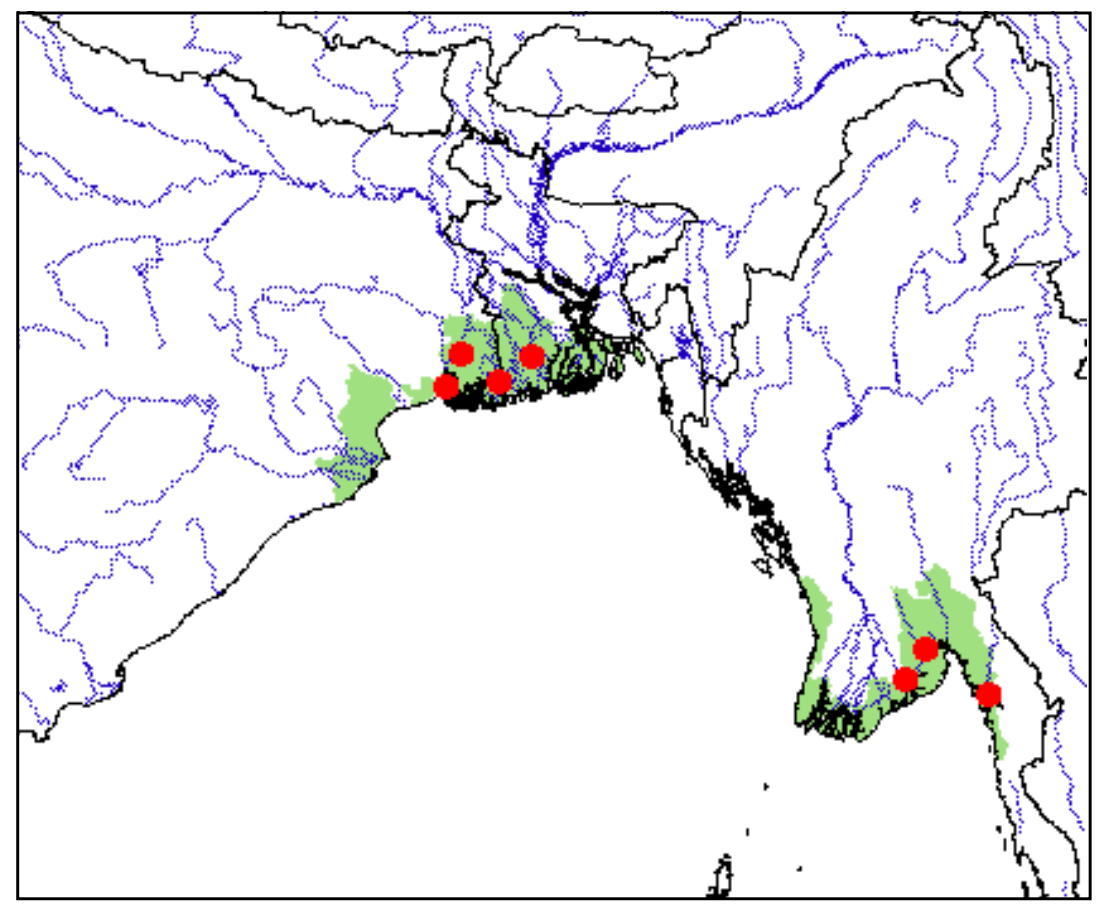

Figure 4. Distribution of Batagur baska in southern Asia in India, Bangladesh, and Myanmar. Red points = museum and literature occurrence records based on Iverson (1992) plus more recent and authors' data; green shading = projected distribution based on GIS-defined hydrologic unit compartments (HUCs) constructed around verified localities and then adding HUCs that connect known point localities in the same watershed or physiographic region, and similar habitats and elevations as verified HUCs (Buhlmann et al., in press), and adjusted based on authors' data.

Batagur, Callagur, and Kachuga comprised a moderately well-supported clade and that the genus Kachuga was clearly paraphyletic. They recommended placing all of the species into a single broader genus Batagur. Based on phylogenetic results and morphological examination of 27 specimens of Batagur, Callagur, and Kachuga, Le et al. (2007) independently and almost contemporaneously came to the same conclusion.

Additionally, Praschag et al. (2007) demonstrated that the formerly widespread species, Batagur baska (sensu lato), comprised at least two genetically distinct species. In a follow-up paper, Praschag et al. (2008b) argued that based on priority, the more northern species (India to Myanmar) should retain the name $B$. baska and that the specific epithet affinis (Cantor 1847) was available for the southern spe-

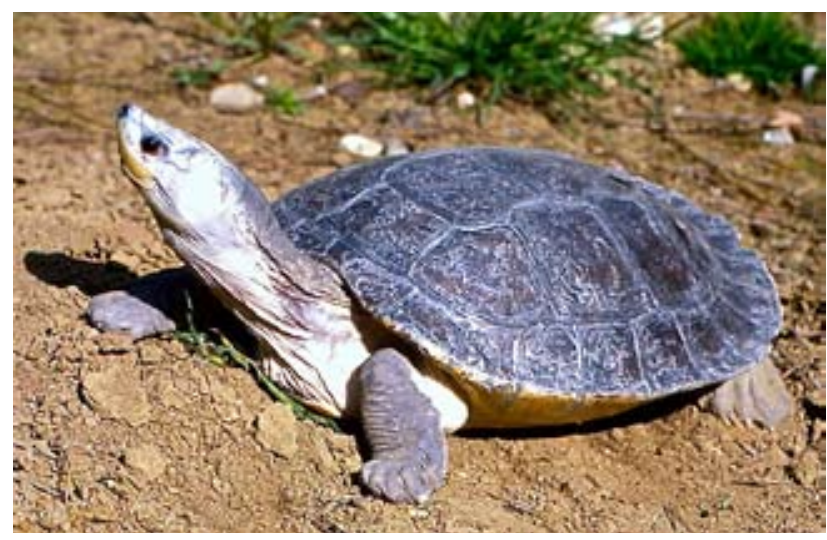

Figure 5. Light-colored female Batagur baska from the Indian Sundarbans. Photo by Peter Praschag. cies occupying Thailand, Malaysia, and Indonesia. Further genetic and morphologic work by Praschag et al. (2009) determined that B. affinis consisted of two subspecies, B.a. affinis in western Peninsular Malaysia and Indonesia, and a new subspecies, B. a.edwardmolli, in eastern Peninsular Malaysia and Cambodia.

Description. - Batagur baska is a large terrapin with a carapace length (CL) of up to $59 \mathrm{~cm}$. It has a deep, massive, heavily buttressed shell, large powerful limbs, and broad fully webbed feet (Fig. 1.). The combination of two denticulate ridges on the triturating surface of the upper jaw (Fig. 2) and four claws, rather than five, on the forefeet separate this species from all others within its range. It differs from its sister species, B. affinis, by its narrower, more pointed snout and by the male breeding coloration (red on neck and limbs, no white iris).

In profile, the head appears relatively small with an attenuated, upturned snout. The jaws are serrate, with the upper bicuspid (a median notch flanked by pointed tooth-like projections) and the lower with a complimentary medial tooth flanked by a shallow notch on each side. The feet are fully webbed with only the tips of the claws extending beyond the webbing. The forelimbs bear a series of transversely elongated band-like scales. A flap of skin, reinforced by enlarged scales, borders the forelimb laterally and merges with the webbing of the toes, giving the limb a paddle-like appearance. Scalation on the hind limb is reduced, but a lateral flap of skin and associated scales are present. The posterior and lateral aspect of the hind-foot is decked with a series of small transversely elongated scales. 
The adult shell is smooth, lacking the marginal spines and vertebral keel present in juveniles. The adult carapace is most elevated anterior to the middle and thereafter slopes off to flatten out along the periphery. The nuchal scute is small and broader than long. The first vertebral scute is squarish but slightly broader in front than behind. Vertebrals 2 and 3 are subequal, 4 is smaller, and 5 is longest, being widest posteriorly. The plastron is truncated anteriorly and shallowly notched posteriorly with the scute formula: $\mathrm{AB}\rangle \mathrm{P}\rangle\langle\mathrm{F}\rangle$ $\mathrm{H}>\mathrm{A}>\mathrm{G}$. The inguinal scute is larger than the axillary.

Shells of females tend to be olive-brown or olive-gray above and pale yellow below, while the soft parts are dull gray to olive-gray anteriorly and lighter gray posteriorly (Fig. 1). The head may be olive or gray (Fig. 2), or even white dorsally (Fig. 5). The eye is black, the tympanic area of the head a light gray to cream, and the mandibles are yellow to a light creamy gray, making them conspicuous at a distance. The snout tip is encircled by a dull, bluish ring.

Anderson (1879) described males in breeding coloration as having the head and ventral part of the neck black, with the coloration of the dorsal portion of the neck to its base depicted as "rich crimson", and the whole of the forelimbs as "brilliant rosy carmine." The hind parts were described as a dull reddish purple. Photographs of Bangladesh males in breeding coloration have been examined (Fig. 3). The shell of these males is brown. The head and ventral portion of the neck is black and the dorsum of the neck, a bright red-orange. However, the forelimbs described by Anderson as "rich crimson" are rust to light orange in these specimens. It is possible that the males photographed by Rashid were not in full breeding colors, however. The iris is dull yellow to yellow-green.

Few measurements are available for wild individuals of this species. The following CL, carapace widths (CW), plastron lengths (PL), and shell heights $(\mathrm{CH})$ are maximum straight line measurements given in millimeters. In the genus Batagur, females typically exceed males in size. The few comparative data confirm this (see below) to be true in the northern river terrapin. Smith (1931) reported the size of $B$. baska as $C L=590 \mathrm{~mm}, \mathrm{CW}=430 \mathrm{~mm}$, and $\mathrm{CH}=210 \mathrm{~mm}$. Although not stated, presumably this was a female. Bhupathy (1995) measured three adult males and two females from the Indian Sundarbans. Males ranged from CL of 385-400 mm (mean 395), and CW of 290-320 mm (mean 303), and had an average mass of $8 \mathrm{~kg}$. Both females had CL $=500 \mathrm{~mm}$ and $\mathrm{CW}=400 \mathrm{~mm}$, but with a mass of 17 and $16 \mathrm{~kg}$, respectively. Measurements of an Indian female reported by Sanyal and Seth (1992) as 400 x $300 \mathrm{~mm}$ and a mass of $19 \mathrm{~kg}$ must be disregarded. The measurements are far too small for a turtle of this mass. Four males measured by Rashid from Bangladesh markets averaged $\mathrm{CL}=421 \mathrm{~mm}, \mathrm{CW}=214 \mathrm{~mm}, \mathrm{PL}=378 \mathrm{~mm}, \mathrm{CH}$ $=161 \mathrm{~mm}$, and mass of $8.87 \mathrm{~kg}$ (Rashid and Swingland 1997). The carapace of a large adult killed by fishermen in Myanmar had a CL $=528 \mathrm{~mm}$ and that of an adult female held in a pagoda pond in Yangon (Rangoon) had a CL = $558 \mathrm{~mm}$ (Platt et al. 2006).
As is characteristic of males in the expanded genus Batagur, the carapace maintains conspicuous costo-peripheral fontanelles. In female Batagur and most other freshwater turtle species, these fontanelles close around maturity. In addition to size, coloration, and the fontanelles, males may be distinguished from females by a longer, thicker, tail.

Sixteen hatchlings from a single clutch in the Indian Sundarbans averaged CL $=60 \mathrm{~mm}, \mathrm{CW}=50 \mathrm{~mm}, \mathrm{PL}=55$ $\mathrm{mm}$, and mass of $41 \mathrm{~g}$ (Moll 1990b). Sanyal and Seth (1992) reported on another group of hatchlings (number not stated) that had an average mass of $45 \mathrm{~g}$.

Distribution. - The northern river terrapin currently ranges from the Sundarbans (an extensive estuary of the Ganges and Brahmaputra Rivers of India and Bangladesh) eastward to the Ayeyarwady and Bago estuaries, and possibly the Thanlwin (Salween) and Sittaung Rivers in Myanmar (formerly Burma) (Iverson 1992).

Literature accounts, verbal reports, and museum specimens suggest that the terrapin was formerly more widespread in the region. The continued existence of populations of river terrapins reported from the Hugli River of West Bengal, India (Günther 1864) and the Subarnareka and Brahmani Rivers of Orissa, India (Annandale 1912; Vijaya 1982; Das 1989) could not be confirmed by recent surveys (Moll 1990b; Praschag et al. 2008a). Annandale (1912) suspected, but could not verify, that the terrapin occurred in the Mahanadi River drainage in India. Recently, Praschag et al. (2008a) interviewed a boatman who collected eggs (possibly from B. baska) on the Devi River, a tributary of the Mahanadi River in Orissa (see 'Population Status'). Saltwater Lake, Calcutta, is the northernmost record from India that is supported by a museum specimen (Das 1989). Another museum specimen from the mid-1800s suggests that the species may also possibly have previously occurred in the Indus Delta of southern Pakistan (Praschag et al. 2008b), but this remains unconfirmed and Pakistan is not considered as part of the natural range of B. baska. Nath (1959) reported old remains of Batagur at Sarnath in Uttar Pradesh, India, but as this site is far removed from the turtle's characteristic mangrove habitats, it is likely a misidentification, possibly based upon the very similar B. kachuga (Moll 1986), or possibly a specimen transported by humans.

Records for Bangladesh have come largely from captives where capture locations have been imprecise or questionable. Based on extensive interviews of fishermen from the southern part of the country, Praschag et al. (2008a) concluded there was a historical presence of the river terrapin from the Sundarbans to the most eastern island (St. Martin) bordering Myanmar.

Platt et al. (2008) found river terrapins in southern Myanmar at scattered locations from the Ayeyarwady Delta southward to the southern-most tip of the country. It is unknown whether these southern populations represent the northern or southern river terrapin (B. affinis).

Habitat and Ecology. - The northern river terrapin is highly aquatic, inhabiting estuaries and tidal portions of large rivers. It inhabited the mouth of the Hugli River in West Ben- 
gal (Günther 1864), estuaries of the Sundarbans of India and Bangladesh (Moll 1985, 1990b; Whitaker 1983) and estuaries associated with Ayeyarwady and Bago River systems of Myanmar (Maxwell 1911; Platt et al. 2006, 2008). Fishermen in the Sundarbans of Bangladesh told Praschag (pers. comm.) that males are typically caught in the estuaries and along the coastline near river mouths, whereas females inhabit more upstream habitats, especially in the nesting season.

Smith (1931) stated that the terrapin was herbivorous, but provided no details. Whitaker (1983) reported that fishermen in Bangladesh caught large numbers of terrapins on hooks baited with the mangrove fruit, Sonneratia apetala. Similarly, Maxwell (1911) reported that Burmese fishermen caught terrapins in traps baited with leaves from the thamè tree (Indian Mangrove, Avicennia officinalis).

Batagur baska populations from India to Myanmar nest on islands and sea beaches near river mouths. Nesting in West Bengal, India, occurs in February and March along with olive ridley sea turtles (Sanyal and Seth 1992; Bhupathy 1995). In the Ayeyarwady Delta of Myanmar, nesting occurs from the end of January through late March (Maxwell 1911).

The best account of nesting behavior is that of Maxwell (1911). Historically, B. baska inhabited the Ayeyarwady Delta, where large numbers nested each year on islands at the river mouth and sandbars as far upstream as Hinthada (formerly Henzada) District. During the nesting season, terrapins assembled at sea beaches in aggregations of 100 to 500 and, irrespective of the tides, they came out of the sea daily at around 1400 hrs to lie abreast of one another and bask until dark. Each night, some emerged to excavate nests, $45-95 \mathrm{~cm}$ deep, in the sand above tidal influence, in which they laid clutches of 10 to 30 eggs. Females reportedly laid three clutches totaling 50 to 60 eggs over a period of six weeks. Sanyal and Seth (1992) described nests in the easternmost beaches of the Indian Sundarbans as being on the upper reaches of the beach in loose sand below Saccharum cylindricum grasses.

Eggs of Ayeyarwady terrapins ranged from $70-75 \mathrm{~mm}$ long by $40-45 \mathrm{~mm}$ wide, with a mass of about $80 \mathrm{~g}$; the period of incubation is around 70 days (Maxwell 1911). Moll (1990b) reported on 17 nests found by the West Bengal Forest Department on Bagnara Island in the Indian Sundarbans between 1988 and 1990. These nests averaged $25 \mathrm{~cm}$ to the top of the eggs and $42 \mathrm{~cm}$ in total depth. Mean clutch size was 31.6 eggs (19-48). Thirty eggs from three nests averaged $72 \times 39 \mathrm{~mm}$ and $69 \mathrm{~g}$. Ghosh and Mandal (1990) reported that three nests from the Indian Sundarbans contained 13, 32, and 37 eggs, averaging $68 \times 40 \mathrm{~mm}$ and $70 \mathrm{~g}$. Sanyal and Seth (1992) reported that 89 eggs collected and reburied in sand hatched after an incubation period of 65 to 66 days, with a hatchling success of $40 \%$. Hatchlings averaged $45 \mathrm{~g}$ in mass.

Population Status. - In India in the 19th century, Blyth (in Günther 1864) reported that B. baska "abounds at the mouth of the Hoogly [Hugli] and great numbers are brought to Calcutta, where they are eaten by particular casts of Hindoos." At that time, river terrapins were a popular substitute for sea turtles in the making of turtle soup (Theobald 1868a, b). Over the last century, and until recently, the commercial trade of turtles in Calcutta has been staggering. Immense numbers were shipped into the fish markets of Calcutta from throughout India (Wedemeyer 1975; Choudhury and Bhupathy 1993). Among the Bengali, the river terrapin was considered the most delectable of all turtles.

There are no recent records of river terrapins from the Hugli and they likely have been extirpated there. If so, water projects affecting the river flow and over-exploitation of the turtles for food are likely causes (Moll 1990b). Also, the most recent river survey of West Bengal and Orissa by Praschag et al. (2008a) found no evidence of the former populations reported from the Subarnarekha and Brahmani Rivers (Vijaya 1982; Das 1989, 1991). However, Praschag (2008a) reported a potential hitherto unknown population from the Devi River, a tributary of the Mahanadi River. The mouth of this river is one of the most important rookeries for the olive ridley sea turtle (Lepidochelys olivacea). A local boatman living upstream of the mouth of the Devi harvested three nests, possibly of B. baska, in 2006 but only one in 2008.

Another vanishing population of Batagur inhabits the Sundarbans, an extensive mangrove estuary comprising a myriad of channels and islands, overlapping the IndiaBangladesh border (Moll 1983, 1985, 1990a, b; Das 1986, $1987,1991)$. The turtle previously nested on the following sand islands: Kanak, Nagbarachar, Kedo, and Mechua (Das 1987, 1991; Ghosh and Mandal 1990). Bhupathy (1995, 1997) found recent evidence of nesting only at Mechua Island in the Sundarban Tiger Reserve, and estimated that as few as 10 nesting females may survive in the region. A forest officer of the Sundarban Tiger Reserve reported that a single river terrapin nested on Mechua Island in 2008.

In Bangladesh, the northern river terrapin was discovered only recently. Khan (1982) traced the collection of a river terrapin in the Dacca Zoological Gardens to the river Mongla, a tributary of the Passur, the largest river in the Bangladesh Sundarbans. Whitaker (1983) met a turtle collector who claimed to catch around 200 Batagur on hooks baited with mangrove fruit in the Sundarbans each year during the monsoon (May-August). The collector told Whitaker that the nesting beaches are located in the southern part of the Chandpai and Sarankola ranges of the Sundarbans. Kali Char and Passur Island were also identified as nesting areas. A captive kept in the collector's village was reported to have been captured at Kaga Khal.

In 1990, coastal areas of Bangladesh were surveyed (Rashid 1990; Moll 1990b). In the Sundarbans, the survey team visited most of the beaches in three of four ranges (Sharankhola, Chandpai, and Khulna), but were unable to confirm any of the nesting sites reported to Whitaker (1983). Four live males and three shells were found in markets in the Khulna and Sarankhola Districts on the periphery of the Sundarbans. However, vendors were reluctant to disclose the localities where the turtles were collected. In 1997, Praschag (unpubl. data) identified a juvenile in a weekly market at 
Mongla and another in the same market in 2007. The latter was allegedly obtained from Chittagong.

Other surveys in eastern Bangladesh found mixed evidence concerning Batagur. One of the most likely habitats, the Chakaria Sundarbans, a lush mangrove forest just north of Cox's Bazar, had recently been destroyed to build salt drying beds (Moll 1990b). Sarker and Hossain (1997) felt that few Batagur survived in the Sundarbans, while a 2005 survey of the Sundarbans by Reza (2005) found none. Praschag et al. (2008a) interviewed a professional turtle catcher that harvested northern river terrapins around Kutubdia Island (near Cox Bazar) during the nesting season. By the late $1990 \mathrm{~s}$, the capture rate no longer paid for the trip. Today, $B$. baska appears to be extirpated from the eastern Chittagong district, but is still caught occasionally in the Sundarbans.

Exploitation along with habitat destruction, such as the removal of the mangrove forests (e.g., near Cox's Bazar) and sand mining (Moll 1997) are likely significant factors in the population's demise. In the course of his survey, Moll (1990b) saw few beaches in populated areas which were not being mined.

In Myanmar, Theobald (1868a) reported Batagur to be common in the south (then known as Pegu). Maxwell (1911) stated that at the turn of the century, an estimated 70,000 eggs were still being harvested per annum. Based on these harvests, Maxwell estimated a nesting population of 1175 females, but thought the numbers of river terrapins appeared to be declining. By licensing turtle egg collectors, the British administration was able to collect statistics indicating that there had been a $53 \%$ decline in egg harvests from 1890 to 1900 .

A 1983 survey by R.E. Salter, a UNDP ecologist who worked in Myanmar during the 1980s, reported that a few Batagur still nested on Kadonlay Kyun off the Ayeyarwady (Irrawaddy) Delta, but no other sites were found. Nesting sites where Maxwell reported thousands of eggs seemingly no longer exist. A more recent survey in 1999 by Thorbjarnarson et al. (2000) found no evidence of extant populations in the lower Ayeyarwady Delta. The current status of the river terrapin on the Thanlwin and Sittaung rivers (sites indicated in Iverson 1992, based on localities of old BMNH museum specimens) has not been investigated. However, Platt et al. (2007) reported reliable descriptions of river terrapins from villagers near Ramree Island (Rakhine State) in western Myanmar. Additional surveys located small populations persisting in the Tha Baung River (Ayeyarwady Division) and scattered localities in southern Tanintharyi Division (Platt et al. 2008), although the viability of these remaining populations is questionable. The persistence of $B$. baska in Myanmar is attributed to a combination of local religious practices that venerate terrapins, and the existence of contested areas where armed conflict between government forces and insurgent groups has been underway for many years (Platt et al. 2008). In effect, these conflict zones (sensu Martin and Szuter 1999) function as de facto nature reserves that remain uninhabited, and fishermen enter at great personal risk (Platt et al. 2008).
Threats to Survival. - The northern river terrapin has been heavily exploited both for its flesh and for its large eggs. In India (Das 1991; Bhupathy 1995) and Bangladesh (Whitaker 1983) both forms of exploitation are significant. Das (1997) considered this species (including B. affinis) as one of tropical Asia's most threatened turtles. In Myanmar, religious beliefs and customs have reduced killing of turtles for food. Nevertheless, exploitation of eggs became highly organized under the British Colonial administration, and included licensing of nesting beaches and commercial sales at rural and urban markets (Maxwell 1911).

Praschag et al. (2008a) recently had an opportunity to investigate the current trade of large river turtles in East India and Bangladesh. They reported that rivers are parceled out to turtle catchers with each allotted a section 20 to $30 \mathrm{~km}$ long. Captured turtles are sent to middlemen that specialize in smuggling turtles to remote areas. Members of the Forest Department and state police are closely involved and turtles are often transported in official vehicles. In this system, every fourth or fifth shipment is seized by the Forest Department. The catchers are not paid for the confiscated shipments; rather, they are sold by corrupt officials to effectively double their profit. Bangladesh operators also enlist turtle catchers in East India to illegally collect for them. They then sell living turtles to local markets and ship the cartilaginous softshell flaps to China. Through middlemen, Praschag asked several forest officers inside the Sundarbans of India and along other rivers to supply him with $B$. baska, and without exception they asked fishermen to catch them for him. Local fishermen know about the terrapin's protected status and eat them immediately to avoid being caught. Based on Praschag's findings, the northern river terrapin is critically endangered in the region and may already be extirpated.

Habitat alteration and destruction are other significant factors leading to the decline of river terrapins in many areas of Asia. Sand mining and dams provide especially serious impacts. Commercial sand removal for construction purposes is destroying nesting beaches throughout tropical Asia (Moll 1990b, 1997; Moll and Moll 2004). Dams located downriver from nesting sites prevent migrations between feeding and nesting sites. Dams upriver from nesting sites do not allow sand to move down river to replenish that lost to erosion or sand mining of nesting beaches. In addition, salinity of the Indian Sundarbans is increasing due to water projects such as the Farakka barrage on the Ganges, which reduces freshwater input to the estuary, leading to loss of mangroves and low saline habitats required by the terrapin (Bhupathy 1995). Large scale water pollution from heavy industry is another serious threat in East Indian rivers (Praschag et al. 2008a). The river Subarnarekha, whose name literally translated means "streak of gold," today has only streaks of untreated sewage, industrial and mineral waste, and even radioactive waste that pollutes the entire ecosystem.

Batagur baska is a critically endangered species in Bangladesh (Rashid and Khan 2000; IUCN Bangladesh 2000). Several limiting factors may be responsible (Moll 1990b). In the Sundarbans at the time of the survey, a combination 
of factors had greatly reduced the production of Sonneratia fruit, a staple in the turtles' diet. The mangroves producing this fruit had been decimated by a combination of lumbering, recent cyclones, and a disease being spread by a boring insect. Exploitation was another significant factor. If Whitaker's (1983) report of fishermen taking some 200 Batagur each season is accurate, then it would not take many years to deplete local populations of these slow-maturing turtles. A major collapse of Indian and Bangladesh populations in the mid- to late 1990s also correlates with a change in fishing techniques. Small rowboats were replaced by motorized fishing trolleys that set wide-area nets, at times reaching from bank to bank of the river mouth, in rich fishing grounds.

Conservation Measures Taken. - Batagur baska is listed as Critically Endangered throughout its range (CR A1bcd) on the 2008 IUCN Red List, based on a range-wide assessment in 2000 (www.iucnredlist.org) that then included the populations now attributed to $B$. affinis. International trade in this species is prohibited by CITES, which lists B. baska (which includes B. affinis) on Appendix I (i.e., prohibited in international commerce by signatory nations). Similarly, India classifies the species on Schedule I of their Wildlife (Protection) Act of 1972, prohibiting all national and international trade.

Myanmar formerly had laws controlling egg collection through licensing of nesting beaches (Maxwell 1911), but with the near extirpation of the terrapin population within the country, such laws are now antiquated. Myanmar Fishery Law protects marine and freshwater turtles, including the river terrapin. The Myanmar Protection of Wildlife, Wild Plants and Conservation of Natural Areas Law of 1994 also protects terrapins, but protected species can be traded with a government permit. However, wildlife laws in Myanmar are poorly enforced, even in protected areas. A conservation action plan has been prepared by Platt et al. (2006). Batagur baska is not listed under the Bangladesh Wildlife Preservation (Amendment) Act (BWPA) 1974 (IUCN Bangladesh, 2000) but may receive protection under the third schedule of the Act that includes animals on Appendix I of CITES as protected species. A 2008 revision of the act, not yet approved, lists $B$. baska as a protected species. Batagur baska is listed as Endangered under the United States Endangered Species Act, and is included in Annex A of European Union (EC) regulation 338/97.

In India in 1988, the West Bengal Forest Department began a small hatchery and captive breeding program for Batagur at the Sajanakhali Batagur Rearing Centre in Pakhiralaya in the Sundarbans Tiger Preserve, after discovering a river terrapin nesting beach at Mechua Island (Bagnara Block) in the Sundarbans of West Bengal (Ghosh and Mandal 1990). Out of the initial 88 eggs collected, 38 (43\%) hatched. Between 1988 and 1991, the Forest Department located 21 more nests and 645 eggs were moved to Sajanakhali to be artificially incubated and the hatchlings reared in captivity. Less than $50 \%$ of the eggs hatched (Bhupathy 1995). Bhupathy etal.(1992) reported that the project was head-starting 175 juveniles in several size classes and had 25 adults, presumably for breeding purposes. Between 1990 and 1994, the Forest Department released 40 captive raised juveniles (2-4 yrs old) in the river Harinbanga of the Sundarbans Tiger Preserve (Bhupathy 1997).

Unfortunately, in the late 1990s, a change in administration led to the abandonment of the river terrapin program in the Sundarbans Tiger Preserve, and the subsequent release of many of the remaining captives. However, in 2008, the pond at Sajanakhali was censused and 12 terrapins ( 8 males, 3 females, and an immature) were captured and at least one other turtle, possibly a female, was seen in the pond (Singh and Saha 2008). The program has now been reinstated. The Turtle Survival Alliance is providing support for husbandry improvements to the pond for basking and nesting (R. Hudson, pers. comm.).

Batagur baska has been recorded from locations covered by several protected areas, though whether viable populations persist is not known. In India, the Indian Sundarbans are a restricted area requiring permit for entry. Within this area, the Sundarbans Tiger Preserve protects all wildlife within its borders. In Bangladesh, the Bangladesh Sundarbans are a World Heritage Site that comprises three wildlife sanctuaries: Sundarban East, Sundarban South, and Sundarban West. Two additional protected areas within the reported range of $B$. baska are Chunati Wildlife Sanctuary and Humchari National Park in southeastern Bangladesh. In Myanmar, Meinmahla Kyun is a protected area at the mouth of the Ayeyarwady River where B. baska once flourished.

Conservation Measures Proposed. - Being critically endangered, the northern river terrapin's plight requires drastic and immediate action to stem further declines. Without exception, countries within the terrapin's range should grant complete protection to the turtle and its eggs, and then promote local, national, and international education programs to publicize its endangerment. Agencies responsible for protecting the turtle and enforcing existing laws (e.g., Forest and Fisheries Departments, State Police, etc.) need to be cleansed of corrupt officials currently involved with illegal trade of river turtles and replaced with conservation-oriented individuals dedicated to enforcing the law.

Based on the most recent surveys, the remaining northern river terrapin in India and Bangladesh appear to be so few and scattered that efforts to save the species in the wild are likely doomed to failure. Unless some previously unknown viable population should be discovered in this region, only the captive breeding approaches listed below offer any hope of success. The situation in Myanmar is less clear and perhaps viable populations may exist in the southern region, but until the political unrest and armed conflict come to an end, little can be done for the terrapin there.

Final decisions on the best approach will depend on results of surveys and whether any viable populations persist. If any can be found,then a combination of ex-situ techniques (i.e., hatcheries, head-starting, captive breeding) coupled with protected areas to maintain the wild population and its habitat is the preferred approach (Moll and Moll 2004). Conversely, if it appears that no viable wild populations 
persist, then the only option is to remove terrapins from the wild and propagate them in captive breeding programs until some future time when a wild population can be reestablished in a secure, protected area.

India appears to be in the best position of the three range countries to take the lead in conserving this species. The people of India traditionally have shown strong concern for the welfare of animals and have supported conservation efforts for species as diverse as crocodiles, sea turtles, rhinos, elephants, and tigers. Furthermore, India has a small captive population of $B$. baska in a protected area at Sajanakhali that can be utilized to study and refine ex-situ techniques for conservation of the terrapin. As the remaining habitat for the terrapin in India adjoins that of Bangladesh, a cooperative program between the two countries would be most effective. Additionally, we recommend the following four steps be taken where feasible:

1. Train a cadre of biologically oriented individuals in natural history and captive husbandry of the river terrapin to administer the conservation program.

2. Survey the former range to determine if viable wild populations still exist and if so, in what localities. Staff should be stationed on known nesting beaches (e.g., Mechua and Bagmara Islands in the Sundarbans Tiger Preserve) during February and March to deter poachers, record nesting, and to obtain females for tracking. In addition, the Forest Department should offer rewards to fisherman and other parties inhabiting the Sundarbans for bringing in unharmed any terrapin that is taken in nets or found nesting (preferably after nesting is complete). Precise locality data of each should be recorded. Captured individuals should be affixed with satellite transmitters. These individuals can then be tracked back to habitats/localities where viable populations may persist and presumably where conditions for survival are at least adequate. Such information will be essential in deciding where and if protected areas should be established, and if offspring resulting from the ex-situ program can be released there.

3. Establish one or more captive breeding centers (multiple centers provide insurance should disease or other catastrophes befall a center). Bhupathy $(1995,1997)$ suggested that existing captives from zoos, captive breeding centers, and village ponds be consolidated into a common captive breeding center. A new survey of zoos and other facilities (e.g., Madras Crocodile Bank Trust) is needed to find if such captive stock is available to merge with the breeding nucleus currently being kept at Sajanakhali to enhance genetic diversity. We concur with this proposal, but if viable wild populations of the terrapin persist, such a program should be self-contained (farming vs. ranching; see Moll and Moll 2004). In other words, all breeding stock should come from captives. Eggs should not be taken from the wild unless they are considered 'doomed' and will likely be lost to factors such as flooding or poaching. Hatchlings or head-started juveniles from the ex-situ program should be used to increase the captive breeding population or restock favorable habitats. Potential problems of the latter include the low success rate of previous projects, the potential for spreading disease, social disruption, and genetic pollution (see Seigel and Dodd 2000; Moll and Moll 2004).

4. Moll and Moll (2004) recommended protected areas as an effective methodology for conserving river turtles. A totally protected reserve has two key advantages: the entire ecosystem is protected, allowing the habitat and community to remain intact, and all stages of the life history are protected and mature naturally.

Mechua Island in the Bagmara Block of the Sundarbans Tiger Preserve may be a likely choice as a focus for terrapin conservation, as it is already part of a protected area and is known to be or has been a nesting site. Additional areas may come to light as a result of tracking as recommended above.

Whichever site(s) are chosen, the following protective measures are recommended.

1.The entire ecosystem should be protected and enforced. No hunting, fishing, or removal of native plants should be allowed.

2. A buffer zone should be established around the island where only limited official boat traffic is allowed.

3. Several trustworthy persons should be stationed on the island during nesting season to protect nesting females from predators, poachers, and other threats.

4. All sand mining should be banned from the site.

5. Nests should be caged if feasible to prevent predators from destroying eggs. Bhupathy (1995) suggested that using pig-proof fencing over the potential nesting area would be more efficient than trying to cage individual nests.

Captive Husbandry. - Praschag (pers. obs.) has observed that, in captivity, juveniles readily feed on a variety of greens (e.g., dandelions, lettuce, aquatic Ipomea), as well as some vegetables and fruit (e.g., carrots, apples), but refuse cabbage and water lettuce (Pistia stratiotes). Juveniles are fond of shrimp and will take trout and carp food pellets.

Bhupathy reported that in 1997, the West Bengal Forest Department had 11 Batagur between their three rearing facilities in the Sundarbans Tiger Preserve at Sajanakhali, at Pakiralaya, Bagna Range Office, and at Jinghahali Beat Office. Ten more were being kept at the AlipurZoo, Calcutta, whereas, 25 others were being kept at Captive Breeding Centres (CBC). In addition, at least 20 others were being kept in captivity at several village ponds in West Bengal.

Updating the above, Praschag (pers. obs.) reports that no river terrapins are currently kept in the aforementioned village ponds. There are indications that a few individuals remain in ponds close to the Bangladesh border, but this is unconfirmed. The last two captives at the Alipur Zoo died in the past few years. Two females that were rescued from the Howra Market by J. Vijaya in the 1980s are kept at the Madras Crocodile Bank. These turtles, and the 13 individuals at Sajanakhali, are the only captive $B$. baska known at the time of this writing. Possibly, several of the males at Sajanakhali could be moved to the Madras Crocodile Bank. This would provide the nucleus for a second captive breeding program, as recommended above. 
Current Research. - Renewed surveys for the species in the Bangladesh Sundarbans are being conducted by S.M.A. Rashid.

Acknowledgments. - We thank Rick Hudson and S.M.A. Rashid for photos.

\section{LITERATURE CITED}

ANDERSON, J. 1879. Anatomical and zoological researches: comprising an account of the zoological results of the two expeditions to western Yunnan in 1868 and 1875. London. Vol. I, 985 pp., Vol. II, plates.

AnNANDALE, N. 1912. The aquatic chelonia of the Mahanaddi and its tributaries. Records of the Indian Museum 7:261-266.

Bhupathy, S. 1995. Status and distribution of the river terrapin Batagur baska in the Sundarbans of India. Final Project Report, SalimAliCentre for Ornithology and Natural History,Coimbatore, India, $37 \mathrm{pp}$.

Bнupathy, S. 1997. Conservation of the endangered river terrapin Batagur baska in the Sundarbans of West Bengal, India. Journal of the Bombay Natural History Society 94:27-35.

Bhupathy, S., Choudhury, B.C., ANd Moll, E.O. 1992. Indian turtle and tortoise conservation project (Technical report May 1991 July 1992). Draft progress report to the Wildlife Institute of India and the U.S. Fish and Wildlife Service, $28 \mathrm{pp}$.

Bour, R. 2009. The types of Tetraonyx longicollis Lesson, 1831 and Tetraonyx lessonii Duméril \& Bibron, 1835, and the confusing history of the generic names Tetronyx Lesson, 1832 and Batagur Gray, 1855. Emys 16(3):30-38.

Buhlmann, K.A., Akre, T.S., Iverson, J.B., Karapatakis, D., MitTERMEIER,R.A.,GEORGES,A.,RHODIN,A.G.J., vANDiJK,P.P., AND GiBBONS, J.W.In press. A global analysis of tortoise and freshwater turtle distributions with identification of priority conservation areas. Chelonian Conservation and Biology 8(2): in press.

CAntor, T. 1847. Catalogue of reptiles inhabiting the Malayan peninsula and islands. Journal of the Asiatic Society of Bengal 16:607-656, 897-952, 1026-1078.

CAPler, J.M. And Moll, E.O. 1990. Phylogenetic relationships of the Batagur complex of tropical Asian turtles. Abstract. Annual Meeting HL/SSAR, Tulane Univ., New Orleans, Louisiana.

Choudhury, B.C. And Bhupathy, S. 1993. Turtle trade in India: A study of tortoises and freshwater turtles. WWF-India (prepared by TRAFFIC- India), New Delhi, India, 50 pp.

DAs, I. 1986. Captive river terrapins of a Sundarbans village. British Herpetological Society Bulletin 17:31-33.

DAS, I. 1987. Status and distribution of estuarine turtles in India. Marine Fisheries Information Service 72:21-22.

DAS, I. 1989. Batagur baska in Orissa. Hamadryad 14:2-3.

DAS, I. 1991. Colour Guide to the Turtles and Tortoises of the Indian Subcontinent. R \& A Publishing Ltd., Avon, England, 133 pp.

DAS, I. 1997. Conservation of tropical Asia's most threatened turtles. In: Abbema, J.V. (Ed.). Proceedings: Conservation, Restoration, and Management of Tortoises and Turtles - An International Conference. New York: New York Turtle and Tortoise Society, pp. 259-301.

DumérIL, A.M.C. And Bibron, G. 1835. Erpétologie Générale ou Histoire Naturelle des Reptiles. Tome Second. Roret, Paris, France, $680 \mathrm{pp}$.

Gaffney, E.S. and Meylan, P.A. 1988. A phylogeny of turtles. In: Benton, M.J. (Ed.). The Phylogeny and Classification of the Tetrapods. Vol. 1. Claredon Press, Oxford, England, pp. 157-219.
GHOSH, A. AND MANDAL, N.R. 1990. Studies on nesting and artificial hatching of the endangered river terrapin Batagur baska (Gray) in the Sundarbans Tiger Reserve, West Bengal. Journal of the Bombay Natural History Society 87:50-52.

GrAY, J.E. 1830a. Illustrations of Indian Zoology, chiefly selected from the collection of Major-General Hardwicke. Vol. I, Part 4, pls. 75, 78. London: Treuttel, Wurtz, Treuttel, Jun. and Richter.

GraY, J.E. 1830b. A Synopsis of the Species of the Class Reptilia. In: Griffith, E. and Pidgeon, E. The Class Reptilia arranged by the Baron Cuvier, with specific descriptions. In: Griffith,E.(Ed.).The Animal KingdomArranged in Conformity with its Organization, by the Baron Cuvier, with Additional Descriptions of all the Species Hitherto Named, and of many not before Noticed. Vol.9. Reptilia. Supplement. London: Whittaker, Treacher, and Co., 110 pp.

Gray, J.E. 1856 ["1855”]. Catalogue of Shield Reptiles in the Collection of the British Museum. Part I. Testudinata (Tortoises). London: British Museum, 79 pp.

GüNTHER, A.C.L.G. 1864. The Reptiles of British India. Robert Hardwicke, London, 452 pp.

HIRAYAMA, R. 1984. Cladistic analysis of batagurine turtles (Batagurinae: Emydidae: Testudinoidea): a preliminary result. Studia Geologica Salmanticensia, Vol. Especial 1. Studia Palaeocheloniologica 1:141-157.

IUCN Bangladesh [Haque, M.N., Khan, M.M.H, Ahmed, R., JoArder, N.B., Islam, A.A., AmeEn, M., AND Nishat, A.]. 2000. Red book of Threatened Amphibians and Reptiles of Bangladesh. IUCN - The World Conservation Union, 95 pp.

IVERSON, J.B. 1992. A revised checklist with distribution maps of the turtles of the world. Privately printed, Richmond, Indiana, $313 \mathrm{pp}$.

KHAN,M.A.R.1982.Chelonians of Bangladesh and their conservation. Journal of the Bombay Natural History Society 79:110-116.

Le, M., McCord, W.P., AND Iverson, J.B. 2007. On the paraphyly of the genus Kachuga (Testudines: Geoemydidae). Molecular Phylogenetics and Evolution 45:398-404.

LESSON, R.P.1831 .Reptiles.In: Bélanger,C.(Ed.). Voyage aux IndesOrientales, par le Nord de l'Europe, les Provinces du Caucase, la Géorgie, l'Armenie, et la Perse...pendant les années 1825-1829. Zoologie. Paris: A. Bertrand, pp. 289-336.

Lesson, R.P. 1832. Illustrations de Zoologie, ou Recueil de figures d'Animaux peintes d'après nature. Pl. 7. Paris: A. Bertrand, 60 pls.

Loveridge, A. AND Williams, E.E. 1957. Revision of the African tortoises and turtles of the suborder Cryptodira. Bulletin of the Museum of Comparative Zoology 115:163-557.

McDowell, S.B. 1964. Partition on the genus Clemmys and related problems in the taxonomy of the aquatic Testudinidae. Proceedings of the Zoological Society of London 143:239-279.

Martin, P.S. AND SzUTER, C.R. 1999. War zones and game sinks in Lewis and Clark's West. Conservation Biology 13:36-45.

MAXwELL, F.D. 1911. Reports on inland and sea fisheries in the Thongwa, Myaungmya, and Bassein Districts and the turtlebanks of the Irrawaddy Division. Government Printing Office, Rangoon, 57 pp.

Moll, D. AND Moll, E.O. 2004. The Ecology, Exploitation, and Conservation of River Turtles. Oxford University Press, New York, 393 pp.

Moll, E.O. 1983. Turtle survey update (January to April 1983). Hamadryad 8:15-17.

MoLl, E.O. 1985. Estuarine turtles of tropical Asia: status and management. Proceedings Symposium: Endangered Marine Animals and Marine Parks 1985(1):214-226.

Molv, E.O. 1986. Survey of the freshwater turtles of India. Part 1: The genus Kachuga. Journal of the Bombay Natural History 
Society 83:538-552.

MoLL,E.O. 1990a.India's freshwaterturtle resource withrecommendations for management. In: Daniel, J.C. and Serrao, J.S. (Eds.). Conservation in Developing Countries: Problems and Prospects. Proceedings of the Centenary Seminar of the Bombay Natural History Society. Bombay Natural History Society and Oxford University Press, Bombay, pp. 501-515.

Moll, E.O. 1990b. Status and management of the river terrapin (Batagur baska) in tropical Asia. Unpublished report of project WWF3901/Asia to the World Wide Fund for Nature, 37 pp.

MoLL,E.O. 1997.Effects of habitat alteration on riverturtles of tropical Asia with emphasis on sand mining and dams. In: Abbema, J.V. (Ed.). Proceedings: Conservation, Restoration, and Management of Tortoises and Turtles - An International Conference. New York Turtle and Tortoise Society, New York, pp. 37-41.

NATH, B. 1959. Animal remains of the 12th Century A.D. from Sarnath, Uttar Pradesh, India. Journal of the Zoological Society of India 10:165-175.

Platt, K., Platt, S.G., Thirakhupt, K., and Rainwater, T.R. 2008. Recent records and conservation status of the critically endangered mangrove terrapin, Batagur baska (Gray, 1831) in Myanmar. Chelonian Conservation and Biology 7:261-265.

Platt, S.G.,Hendrie, D., Chan, E.H.,Poynter, B.,Platt, K., Sovannara, H., Holloway, R., Myo, K.M., Chen, P.N., and Soh, C.L. 2006. Batagur baska: A status review and conservation action plan. Unpublished report to Wildlife Conservation Society and Turtle Survival Alliance, $68 \mathrm{pp}$.

Platt, S.G., Kalyar, Win Ko Ko, Kin Myo Myo, Lay Lay Khaing, AND RAINWATER,T.R. 2007. Notes on the occurrence, natural history, and conservation status of turtles in central Rakhine (Arakan) State, Myanmar. Hamadryad 31:202-211.

Praschag,P.,HundSDÖrfER,A.K., AND Fritz,U.2007.Phylogeny and taxonomy of endangered South and South-east Asian freshwater turtles elucidated by mtDNA sequence variation (Testudines: Geoemydidae:Batagur, Callagur, Hardella,Kachuga,Pangshura). Zoologica Scripta 36:429-442.

Praschag, P., Ghose, R., And Wollinger, F. 2008a. Field survey for the river terrapin (Batagur baska) in East India and Bangladesh. TSA, Turtle Survival Alliance Newsletter, August, p. 30.

Praschag, P., Sommer, R.S., McCarthy, C., Gemel R., and Fritz, U. 2008b. Naming one of the world's rarest chelonians, the southern Batagur. Zootaxa 1758:61-68.

Praschag,P.,Holloway, R.,Georges,A.,Päckert, M.,Hundsdörfer, A.K., AND Fritz, U. 2009. A new subspecies of Batagur affinis (Cantor, 1847), one of the world's most critically endangered chelonians (Testudines: Geoemydidae). Zootaxa 2233:57-68.

RASHID, S.M.A. 1990. Status and management of the river terrapin in tropical Asia: Sundarbans, Bangladesh. Unpublished final report for World Wide Fund for Nature project 3901/Asia., 7 pp.

RASHID, S.M.A. AND KHAN, S.M.M.H. 2000. Trade and conservation status of freshwaterturtles in Bangladesh.In: VanDijk,P.P., Stuart, B.L., and Rhodin,A.G.J.(Eds.).Asian Turtle Trade: Proceedings of a Workshop on Conservation and Trade of Freshwater Turtles and Tortoises in Asia, Phnom Penh, Cambodia. Chelonian Research Monographs 2:77-85.

RASHID, S.M.A. AND SwINGLAND I.R. 1997. On the ecology of some freshwater turtles in Bangladesh. In: Abbema, J.V.(Ed.). Proceedings: Conservation, Restoration, and Management of Tortoises and Turtles - An International Conference. New York Turtle and Tortoise Society, New York, pp. 225-242.

ReZA, A.A. 2005. Current status of river terrapin, Batagur baska in Bangladesh. Unpublished Report, Department of Zoology, Jahangirnagar University, Dhaka, Bangladesh. 12 pp.

SANYAL, P. AND SETH, S. 1992. Rare terrapin (Batagur baska) breeding in Bengal. Tiger Paper 19(4):10-11.

SALTER, R.E. 1983. Summary of currently available information on internationally threatened wildlife species in Burma. Nature Conservation and National Parks Project Burma. Unpublished Report to FAO, Rangoon, Burma, 24 pp.

SARKER, S.U. AND HossaIN, L. 1997. Population and habitat status of freshwater turtles and tortoises of Bangladesh and their conservation aspects. In: Abbema, J.V. (Ed.). Proceedings: Conservation, Restoration, and Management of Tortoises and Turtles - An International Conference. New York Turtle and Tortoise Society, New York, pp. 290-294.

SEIGEL, R.A. AND Dodd, C. K. 2000. Manipulation of turtle populations for conservation: Halfway technologies or viable options? In: Klemens, M.W. (Ed.). Turtle Conservation. Smithsonian Institution Press, Washington, D.C., pp. 218-238.

SingH, S. AND SAHA, B.K. 2008. Impression report on a visit to assess the resources and potentials to conserve the River terrapin; Batagur baska in the Sundarban. Unpublished report submitted to the Principal Chief Conservator of Forest (Wildlife) and the Chief Wildlife Warden, Government of West Bengal, 6 pp.

Sмiтн, M.A. 1931. The Fauna of British India, including Ceylon and Burma. Reptilia and Amphibia. Vol. I. Loricata, Testudines. Taylor and Francis, London, 185 pp.

SPINKS, P.Q., SHAFFER, H.B., Iverson, J.B., AND McCord, W.P. 2004. Phylogenetic hypotheses for the turtle family Geoemydidae. Molecular Phylogenetics and Evolution 32:164-182.

Temminck, C.J. and Schlegel, H. 1835. Reptilia Elaborantibus. I. Chelonii. In: Siebold, P.F. von. Fauna Japonica, Vol. III, Lugduni, Batavorum, pp.1-80.

Theobald, W., JR. 1868a. Catalogue of the reptiles of British Birma, embracing the provinces of Pegu,Martaban, and Tenasserim; with descriptions of new or little-known species. Journal of the Linnean Society (Zoology) 10:4-67.

Theobald, W., JR. 1868b. Catalogue of Reptiles in the Museum of the Asiatic Society of Bengal. Journal of the Asiatic Society of Bengal, Extra Number, 88 pp.

Thorbuarnarson, J., Platt, S.G., and Khaing, S.T. 2000. Conservation status of freshwater turtles in Meinmahla Kyun Wildlife Sanctuary and vicinity, Myanmar. Natural History Bulletin of the Siam Society 48:185-191.

ViJAYA, J. 1982. Freshwater turtles. Hamadryad 7:11-13.

WedEMAYER, F. 1975. Schildkrötenmarkt in Kalkutta. DATZ 28:138-139.

Whitaker, R. 1983. Bangladesh: a general survey. Hornbill 1983:3-9.

\section{Citation Format for this Account:}

Moll, E.O., Platt, K., Platt, S.G.,Praschag, P., and van Dijk, P.P. 2009. Batagur baska (Gray 1830) - northern river terrapin. In: Rhodin, A.G.J., Pritchard, P.C.H., van Dijk, P.P., Saumure, R.A., Buhlmann, K.A., Iverson, J.B., and Mittermeier, R.A. (Eds.). Conservation Biology of Freshwater Turtles and Tortoises: A Compilation Project of the IUCN/SSC Tortoise and Freshwater Turtle Specialist Group. Chelonian Research Monographs No. 5, pp. 037.1-037.10, doi:10.3854/crm.5.037.baska.v1.2009, http:// www.iucn-tftsg.org/cbftt/. 